\title{
Effect of Rock Climbing Training on Strength, Speed and Endurance
}

\author{
Kasundra $^{1}$ P. M., Jethwa, Y. L. ${ }^{2}$
}

${ }^{1}$ Associate Professor. Mahadev Desai Sharirik Shikshan Mahavidyalaya - Sadra Gujarat Vidyapith, Gujarat. ${ }^{2}$ Mahadev Desai Sharirik Shikshan Mahavidyalaya - Sadra, (Honorary Instructor) SVIM Mount Abu, Rajsthan.

\section{Abstract}

The aim of this study was to determine the effect of 28 Days Rock Climbing Training Program on physical fitness components such as strength endurance of shoulder and abdominal muscles, speed and endurance. Trainees of 72-Coaching Course ( $\mathrm{N}=22$, Male, Age Range $=16-27 \mathrm{yrs})$ were selected as the subjects for the study. Pull Ups, Sit Ups, 50 Yard Dash and 11/2 Mile Run/Walk tests were respectively used to measure selected variables. By comparing pre and post test data, at 0.05 level; significant differences were found in strength endurance of shoulder muscles ( $(\mathrm{t}$ ' $=2.19)$, strength endurance of abdominal muscles $(' \mathrm{t}$ ' $=10.25)$, speed $(' t '=9.82)$, and endurance $(' t '=6.83)$. Here strength endurance of abdominal muscles and shoulder muscles, and endurance improved significantly while speed decreased. It is recommended that improvement in climbing performance is best explained by trainable variables such as shoulder and forearm strength and endurance; furthermore strength and conditioning programs should not be viewed as a replacement of climbing but rather as supplementary during courses.

Key Words: Rock Climbing Training, Strength Endurance, Shoulder \& Abdominal Muscles,

\section{Introduction}

Mountaineering as a sport consists of ascending and descending mountains under the climber's own power. At one end are the relatively gentle climbs for which climbers need little of equipment; at the other are ascents of the world's highest and most daunting peaks, involving months and years of preparation. Mountaineering and its companion sport, rock climbing is simultaneously recreational and competitive. They are recreational in the sense that most climbers climb for love of the sport, but competitive when climbers seek to climb first, highest, or by a new route. In recent years, both men and women have adapted mountaineering and rock-climbing techniques to indoor-sport climbing on vertical surface.

The sport of rock climbing evolved from this ancient tradition of climbing mountains. Climbing skills and techniques were developed by mountaineers attempting to climb the lower, steeper mountains and cliffs. Safety equipment was finally introduced in the early 1900's, and the development of light weight shoes, improvements in equipment design, and artificial climbing aids during the 1960's enabled climbers to focus more on style and technique. To meet the demands of this growing sport, climber needs some sort of physical and mental toughness like other sports.

A sport performance depends on at least 5 components: energetic capacity, consisting of an anaerobic and aerobic part, tactics, technique, and motivation of the sportsmen for maximum use of their potentials on the sporting field (Balabinis et al, 2003; Rodio et al, 2008; Gacesa et al, 2009). All these components represent complex functional systems, which are created and modified during physical activities. The quality of these interactions determines sport result. Because of the different influences that each component 
has on sport performance and results, every sport discipline must be observed individually. When it comes to physical fitness required for climbing, strength and power are two vital factors for successful performance. Researches have shown that success in climbing performance is best explained by trainable variables such as shoulder strength and endurance, forearm strength and endurance, and maximum grip strength, rather than anthropometric characteristics such as height and weight. To achieve this level of physical fitness one require increase in the duration of a specific exercise movement i.e. pull-ups slowly and concentrate on duration rather than the number of pull-ups.

\section{Materials and Methods}

Trainees of 72 Coaching Course were studied at baseline and after the completion of training. The core of the study was to determine the effects of 28 days of Rock Climbing Training Program on Strength Endurance of Shoulder Muscles and Abdominal Muscles, Speed and Endurance. Twenty two male trainees (age range 16 to 27 years) were selected as the subjects for the study who joined the Rock Climbing Coaching Course during the summer of 2010. Selected variables were assessed respectively by Pull ups test; 1 min Sit ups test, 50 Yard Dash and 1/1/2 Mile Run/Walk Test. Life style and health related habits of an individual were the limitations of the study. Rocks climbing being an adventurous sport, subjects were likely to be prone to physical hazards. Injury or ill health during tests was uncontrolled which might affect the performance. It was hypothesized that 28 days training program affects Strength Endurance of Abdominal Muscles and Shoulder Muscles, Speed and Endurance.

\section{Training Schedule}

\begin{tabular}{|c|c|c|c|c|}
\hline No & & & $\begin{array}{c}\text { Part of Training Session } \\
\text { its contents }\end{array}$ & Remark \\
\hline \multirow{3}{*}{1} & \multirow{3}{*}{$\begin{array}{l}\text { Day } \\
1^{\text {st }}\end{array}$} & $1^{\text {st }}$ & $\begin{array}{l}\text { Jogging for } 20 \text { minutes } \\
\text { \& acclimatization walk }\end{array}$ & \multirow{3}{*}{$\begin{array}{l}\text { Basic level } \\
\text { Basic level }\end{array}$} \\
\hline & & $2^{\text {nd }}$ & Climbing practice & \\
\hline & & $3^{\text {rd }}$ & Rappelling practice & \\
\hline \multirow{3}{*}{2} & \multirow{3}{*}{$\begin{array}{l}2-3- \\
4\end{array}$} & $1^{\text {st }}$ & $\begin{array}{l}\text { Jogging \& running for } \\
25 \text { minutes. Warm up } \\
\text { exercises \& climbing } \\
\text { practice }\end{array}$ & Basic level \\
\hline & & $2^{\text {nd }}$ & Climbing practice & $\begin{array}{l}\text { Basic/ } \\
\text { Advance } \\
\text { level }\end{array}$ \\
\hline & & $3^{\text {rd }}$ & Rappelling practice & Basic level \\
\hline \multirow[t]{2}{*}{3} & \multirow[t]{2}{*}{$5-10$} & $\begin{array}{l}1^{\text {st }} \\
\& \\
2^{\text {nd }}\end{array}$ & $\begin{array}{l}\text { Conditioning \& team- } \\
\text { climbing on Arbuda } \\
\text { Wall }\end{array}$ & $\begin{array}{l}\text { Advance } \\
\text { level }\end{array}$ \\
\hline & & $3^{\text {rd }}$ & $\begin{array}{l}\text { Over hang - Rappelling } \\
\text { practice }\end{array}$ & $\begin{array}{l}\text { Basic/advan } \\
\text { ce }\end{array}$ \\
\hline 4 & 11 & - & One day night halt & \\
\hline \multirow[t]{2}{*}{5} & \multirow[t]{2}{*}{12} & $\begin{array}{l}1^{\text {st }} \\
\& \\
2^{\text {nd }}\end{array}$ & $\begin{array}{l}\text { Climbing unknown } \\
\text { rocks }\end{array}$ & \\
\hline & & $3^{\text {rd }}$ & $\begin{array}{l}\text { Knots practice \& night } \\
\text { track }\end{array}$ & \\
\hline \multirow[t]{2}{*}{6} & \multirow[t]{2}{*}{$\begin{array}{l}13- \\
14\end{array}$} & & $\begin{array}{l}\text { Alternate leading on } \\
\text { Arbuda Wall }\end{array}$ & Advance \\
\hline & & 3rd & $\begin{array}{l}\text { Over hang Rappelling } \\
\text { (Toad Rock) }\end{array}$ & Advance \\
\hline \multirow[t]{2}{*}{7} & \multirow[t]{2}{*}{15} & $\begin{array}{l}1^{\text {st }} \\
\& \\
2^{\text {nd }}\end{array}$ & Rest \& lecture & \\
\hline & & $3^{\text {rd }}$ & Rappelling & Advance \\
\hline 8 & $\begin{array}{l}16- \\
18\end{array}$ & & Night Halt & \\
\hline 9 & 19 & & $\begin{array}{l}\text { Climbing unknown } \\
\text { rocks }\end{array}$ & \\
\hline 10 & $\begin{array}{l}20- \\
21\end{array}$ & & Artificial climbing & $\begin{array}{l}\text { Advance/Te } \\
\text { chnical }\end{array}$ \\
\hline 11 & $\begin{array}{l}22- \\
24\end{array}$ & & Arbuda wall climbing & Advance \\
\hline 12 & 25 & & $\begin{array}{l}\text { Building Climbing, } \\
\text { Penetration, \& Building } \\
\text { Rescue }\end{array}$ & $\begin{array}{l}\text { Advance/Te } \\
\text { chnical }\end{array}$ \\
\hline 13 & $\begin{array}{l}26- \\
27\end{array}$ & & $\begin{array}{l}\text { Climbing \& Rappelling } \\
\text { practice }\end{array}$ & \\
\hline 14 & 28 & & $\begin{array}{l}\text { Climbing practice \& } \\
\text { Examination }\end{array}$ & \\
\hline
\end{tabular}

Generally, training schedule was divided into three sessions, two in the morning; each of two hrs and one in the evening of two and half hrs duration. From 22-26 selected trainees were assigned for apprenticeship. Each regular morning session consisted of warm-up exercises for 20 to 30 minutes. 
Analysis of Data

For the statistical procedure paired t-test (one tailed test) was used to test the hypothesis. The significance level was 0.05 .

\begin{tabular}{ccll}
\multicolumn{2}{c}{ Test Criteria: } & \\
\hline No & \multicolumn{1}{c}{ Test } & \multicolumn{1}{c}{ Variable } & $\begin{array}{l}\text { Unit of } \\
\text { Measurement }\end{array}$ \\
\hline 1 & Pull Ups & $\begin{array}{l}\text { Strength } \\
\text { Endurance } \\
\text { Shoulder Muscles } \\
\text { Strength } \\
\text { Endurance } \\
\text { Abdominal } \\
\text { Muscles } \\
\text { Speed }\end{array}$ & $\begin{array}{l}\text { Number of } \\
\text { Pull Ups in } \\
\text { one attempt }\end{array}$ \\
2 & Sit Ups & $\begin{array}{l}\text { Number of } \\
\text { Sit Ups in 6o } \\
\text { Sec. }\end{array}$ \\
3 & $\begin{array}{l}\text { 50 Yard Dash } \\
\text { Sec. }\end{array}$ \\
4 & $\begin{array}{l}1 / 2 \text { Mile } \\
\text { Run/Walk } \\
\text { Test }\end{array}$ & Endurance & Minutes:Secs \\
\hline
\end{tabular}

\section{Results \& Discussion}

Table 1: Effects of 28 days of Rock Climbing Training Program on Strength Endurance of Shoulder, Abdominal Muscles, Speed and Endurance

\begin{tabular}{|c|c|c|c|c|c|}
\hline Test & $\begin{array}{c}\text { Pre } \\
\text { Test } \\
\text { Mean } \\
\end{array}$ & $\begin{array}{c}\text { Post } \\
\text { Test } \\
\text { Mean } \\
\end{array}$ & $\begin{array}{c}\text { Mean } \\
\text { Difference }\end{array}$ & SD & $\begin{array}{c}\text { 't' } \\
\text { Ratio }\end{array}$ \\
\hline Pull Ups & 7.90 & 8.95 & 1.05 & 2.24 & $2.19 *$ \\
\hline Sit Ups & 22.45 & 30.23 & 7.77 & 3.55 & $10.25 *$ \\
\hline $\begin{array}{l}50 \text { Yard } \\
\text { Dash }\end{array}$ & 7.25 & 8.18 & 0.94 & 0.45 & $9.82 *$ \\
\hline $\begin{array}{l}1 / 2 \text { Mile } \\
\text { Run/Walk } \\
\text { Test }\end{array}$ & 12.20 & 10.52 & 1.68 & 1.15 & $6.83 *$ \\
\hline
\end{tabular}

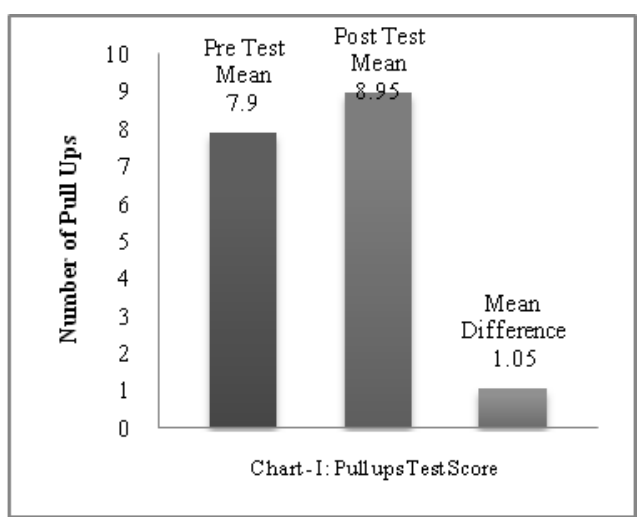

Analysis of the pretesting and post testing performance score showed significant improvement in Pull Ups test. $t$ is observed to be 2.19 with the mean difference of 1.05 (chart I).

Analysis of the pretesting and post testing performance score showed significant improvement in Sit Ups test. $t$ was found to be 10.25 that is highly significant in statistical terms with the mean difference of 7.77 (chart II).

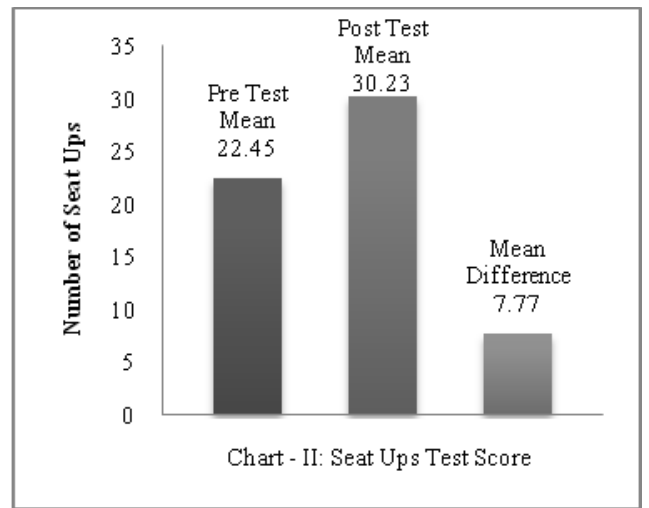

Analysis of the pretesting and post testing performance score showed significant improvement in $1 \frac{1}{2}$ Mile Run/Walk test. $\mathrm{t}$ is observed to be 6.83 with the mean difference of 1.68 significant statistically (chart IV).

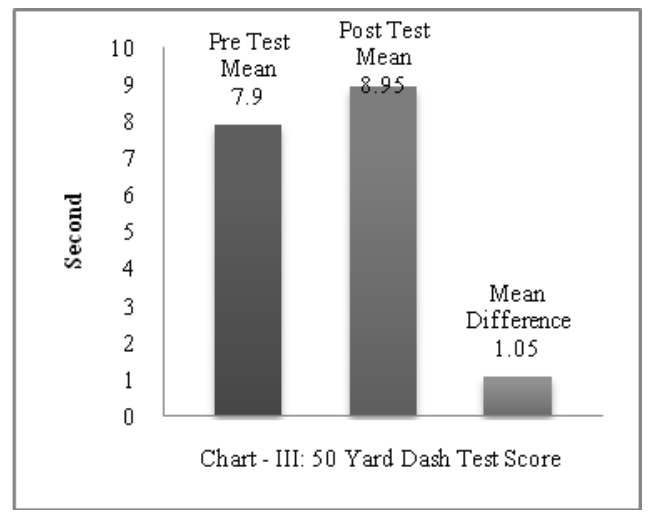


There was a significant decline in speed test performance from pre test to post test. $\mathrm{t}$ value was observed to be 9.82 with mean difference of 0.45 (chart III).

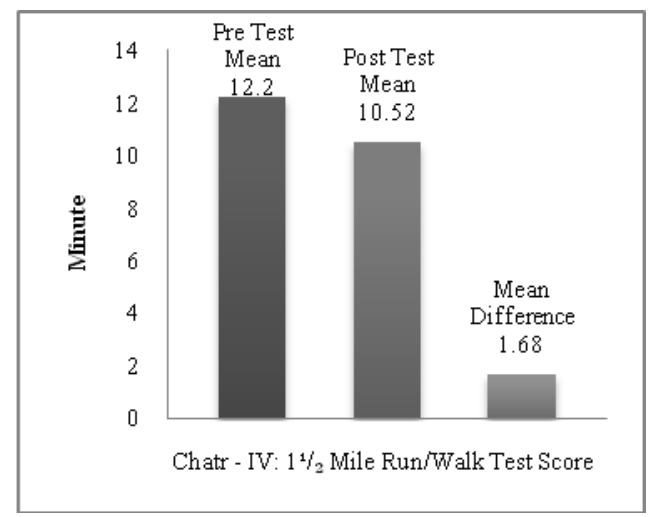

The results of the study reveal that 28 days of Rock Climbing Training Program lead to significant improvements in strength-endurance of shoulder and abdominal muscles, while speed decreased significantly. Concurrent strength and endurance training seems to have caused compromise between strength gains and the ability to produce explosive movements. Possible reasons for compromise in strength-power adoptions with concurrent training are an increased likelihood of differences in the organization of neuromuscular recruitment patterns; alterations in the concentrations of various hormones and differences in activation or repression of various anabolic-catabolic processes at the muscular level; and shifts in protein isozymes such as myosin. Some researches suggest that strength training may enhance endurance performance, although there are reasons to believe that resistance training can also be detrimental. Further research is necessary to determine the extent to which strength adaptations are compromised with concurrent training, and the mechanisms by which combined training negatively affects strength. It is recommended that improvement in climbing performance is best explained by trainable variables such as shoulder and forearm strength and endurance; furthermore strength and conditioning programs should not be viewed as a replacement of climbing but rather as supplementary during courses.

\section{Practical Applications}

The muscles that tend to get tight after long hikes with a loaded pack are hips, lower back, calves, quads, glutes, hip flexors, shoulders and hamstrings, all to the varying degrees depending on individual body types. The forearms and fingers tend to experience the most exertion and fatigue during vertical climbing, particularly the flexors. Good muscular-endurance and strength of the arms and shoulders are beneficial for climbing. Results of the study may be helpful to the rock climbing coaches to evaluate the training program. Furthermore the study may be helpful to redesign the training program in accordance with the required level of physical fitness for this particular activity. The study may be helpful to motivate and guide new comers for such activity.

\section{Acknowledgement}

The researchers wish to thank the Swami Vivekananda Institute of Mountaineering, Mount Abu for the grant of permission to conduct this research. The researchers are also indebted to the faculty members of Mahadev Desai Sharirik Shikshan Mahavidyalaya Sadra, Gandhinagar, Gujarat for their guidance and encouragement.

\section{References}

Balabinis, C.P., Psarakis, C.H., Markos Moukas, M., Vassiliou, M.P., Behrakis, P.K. 2003: Early Phase Changes by Concurrent 
Endurance and Strength Training. J. of Str. \& Cond. Res. 17(2): 393-401

Green, Jaxkson G and Stannard, Stephen R. June 2010: Active Recovery Strategies and Handgrip Performance in Trained vs. untrained climbers. J. Stren. \& Condit. Res. 24(6): 1705

Gacesa, P.; Jelena Z; Barak, O. F; Grujic, Nikola, G. 2009: Maximal Anaerobic Power Test in Athletes of Different Sport Disciplines. J. Stren. \& Condit. Res. 23(3):751-755.

Christensen, K., Guttmann, A., Pfister, G. 2001: International Encyclopedia of Women and Sports - Volume II, Macmillan Reference. USA pg no - 760

Martino, M., Myers, K., \& Bishop, P. 1995: Effects of 21 days training at altitude on sea-level anaerobic performance in competitive swimmers. Med. and Sci. Sports and Exerc., 27 Supplement, (Abstract 37)

Rodio, A.; Fattorini, L.; Rosponi, A.; Quattrini, Fi. M. \& Marchetti, M. 2008: Physiological Adaptation in Noncompetitive Rock Climbers: Good for Aerobic Fitness? J. Stren. \& Condit. Res. 22(2): 359-364.

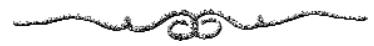

